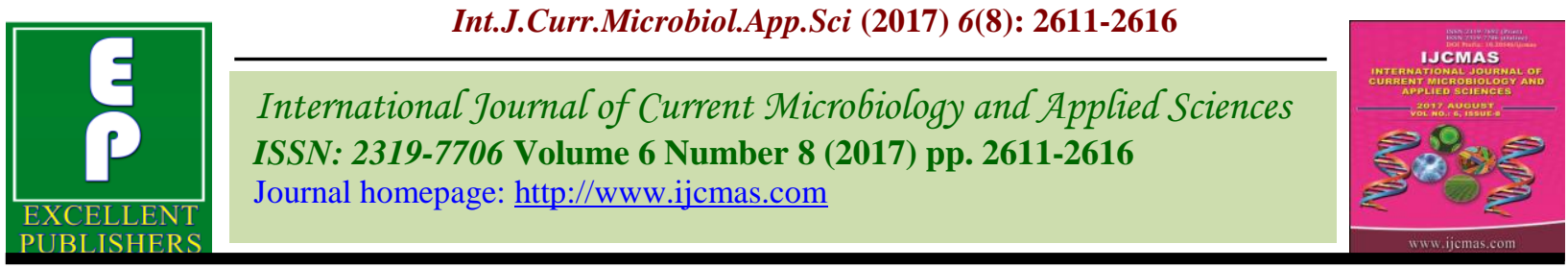

Original Research Article

https://doi.org/10.20546/ijcmas.2017.608.310

\title{
Incidence of Rust, Powdery Mildew and Wilt in Pea and Broad bean Plant of Manipur, India
}

\author{
Nabakishor Nongmaithem*, Ch. Basudha and Susheel Kumar Sharma \\ ICAR Research Complex for NEH Region, Manipur Centre, Lamphelphat-795004, India \\ *Corresponding author
}

Keywords

Disease incidence,

Pea, Broadbean.

Powdery mildew,

Rust, Wilt.

Article Info

Accepted:

21 June 2017

Available Online:

10 August 2017

\section{A B S T R A C T}

Rust, powdery mildew and wilt are major diseases of pea and broad bean of worldwide distribution. Due to high humidity region of Manipur these diseases are the major limiting factors which reduce the yield and productivity of the crop. It is particularly damaging in late sowings or in late maturing varieties. Rust and powdery mildew is an airborne disease whereas wilt is a soil borne disease which can causes $25-50$ percent yield losses, reducing total yield biomass, number of pods per plant, number of seeds per pod, plant height and number of nodes. The disease also affects green pea quality. The disease incidence in Imphal and Chandel district was in the range between 5-55 percent. The diseases were found to be more prevalence in Chandel than Imphal district. The maximum disease incidence of 55 percent rust of broad bean was recorded followed by powdery mildew of pea which show 45 percent disease incidence and same disease incidence of 15 percent was recorded both in wilt of pea and broad bean.

\section{Introduction}

India is the largest producer, consumer and importer of pulses in the world. In India pulses are grown about 24-26 million hectares of area producing 17-19 million tonnes of pulses annually. India accounts for over one third of the total world area and over 20 per cent of total world pulse production. In Manipur, a north eastern hill state of India, field pea is the major pulse crop grown in 26,000 ha area occupying about $85 \%$ of the total pulses area (Anonymous, 2015). There is huge deficit in production of pulses in Manipur state as against the requirement mainly due to lack of improved varieties with tolerance to acidity of soil, a characteristic feature of the soils of North East, in general. Also, the crop is mainly grown in marginal and sub marginal lands with residual moisture of soil during winter mostly under rice fallow condition. The area under faba bean crop in India is very less and that is why it is still categorized as minor, unutilized, underutilized, less utilized, and still not fully exploited crops. Faba bean cannot only be grown on diver's agro-climatic conditions successfully, but it can also be produced on 
residual soil moisture, relatively more tolerant to biotic and abiotic stress, with minimum input (Singh and Bhatt, 2012a; Singh and Kumar, 2009). Among the various diseases of pea and broad bean Powdery mildew, rust and wilt are three major diseases causing severe loss with in short period of time. Powdery mildew appears in epidemic form when the plants are in the pod stage towards the end of January and in February.

The disease is characterized by the formation of white, floury patches initially on the leaf progressing towards tendrils, pods and stems covering most of the aerial part at advancement of the disease. The losses in yield in a $100 \%$ infected crop were estimated to be $21-31 \%$ in pod number and $26-47 \%$ in pod weight (Munjal et al., 1963). The pathogen causes up to $50 \%$ yield losses and reduces pod quality (Dixon, 1987). Rust (Uromyces viciae-fabae) appears as orangebrown pustules with a light green halo on leaves, which can spread to stems (Ali et al., 2000). Vascular wilt caused by Fusarium sp. is soil borne disease of worldwide distribution and it is one of the most important diseases of pea and broad bean (Phal and Choudhary, 1983; Sharma et al., 1989; Lin, 1991; Kraft, 1994; Maheshwari and Gandhi, 1998). The diseases can cause $25-50 \%$ yield losses (Munjal et al., 1963; Warkentin et al., 1996), reducing total yield biomass, number of pods per plant, number of seeds per pod, plant height and number of nodes (Gritton and Ebert 1975). The disease can also hasten crop maturity, rapidly raising tenderometer values beyond optimal green pea harvesting levels (Falloon and Viljanen-Rollinson 2001).

Manipur being a high humid region and its association with cloudy weather results into spread of fungal diseases like powdery mildew, rust and vascular wilt diseases which are considered as three major important diseases of pea and broad bean. So, in this presence investigation survey was conducted at Imphal and Chandel district of Manipur and disease incidence was recorded for rust, powdery mildew and wilt of pea and broad bean.

\section{Materials and Methods}

During January and February, 2017 survey on rust, powdery mildew of pea and broad bean were carried out at Imphal and Chandel district of Manipur. Observations of the disease severity were recorded by random sampling technique from 10 plants from farmer's field on 0-5 scale suggested by Mayee and Datar, 1986 for rust while 0-9 scale for powdery mildew as suggested by Saari and Prescott, 1975 shown in tables 1 and 2 respectively.

$\mathrm{PDI}=\left[\sum\right.$ (Class rating $\mathrm{X}$ Class frequency)/(Total numbers of plant scored $\mathrm{x}$ Maximum rating) $\mathrm{x} 100]$.

Survey of pea and broad bean fields was also carried out for occurrence of wilted plants of each spot. Three plots were taken for recording of wilted plant. In each plot two spot of one meter square quadrant were taken at random and each spot having wilted as well as healthy plants were recorded. The per cent occurrence of wilted plants of each spot was calculated as following .

$\%$ occurrence of wilted plants of each spot= (Number of wilted plants of each spot/total number of plants of the same spot) x 100 .

\section{Results and Discussion}

The disease incidence ranged between 5 to 55 per cent for rust, powdery mildew and wilt of pea and broad bean (Table 1). The maximum disease incidence of 55 percent was recorded in broad bean rust caused by Uromyces fabae followed by powdery mildew and rust of pea 
which showed disease incidence of 45 percent and 40 percent respectively. The minimum disease incidence of 10 percent was recorded in wilt of broad bean and same incidence of 15 percent was recorded in wilt of pea and powdery mildew of broad bean respectively.

Thus, the survey during January to march, 2017 revealed that there is the prevalence of rust disease in Manipur. About 35 and 50 percent pea and broad bean rust were recorded from imphal district while 40 percent was recorded in pea and 55 percent in broad bean plant in chandel district. The disease was found to be more severe in chandel than imphal district of Manipur. The rust disease of pea and broad bean were shown in fig 1 and fig 2 respectively. There were reports of occurrence of $U$. fabae from different parts of the country including eastern India (Chand et al., 1997; Gupta, 1990), central India (Narsinghani et al., 1980), and southern parts of India (Sokhi et al., 1974; Kumar et al., 1994) and from Himalayan region of Uttarakhand and Himachal Pradesh (Sharma, 1998; Chauhan et al., 1991). Prasada and Verma, 1948 reported the occurrence of $U$. fabae on lentil crop from Delhi. Roy, 1949 in his list of fungi of Bengal recorded the prevalence of $U$. fabae on the leaves and stems of pea (Pisum sativum). Faba bean rust in manipur can occur from mid spring onwards and is favoured by warm temperatures (above $20^{\circ} \mathrm{C}$ ). Rust infection can occur following 6 hours of leaf wetness, so does not require extended wet periods.

Fig.1 Rust of pea

Fig.2 Rust of broad bean

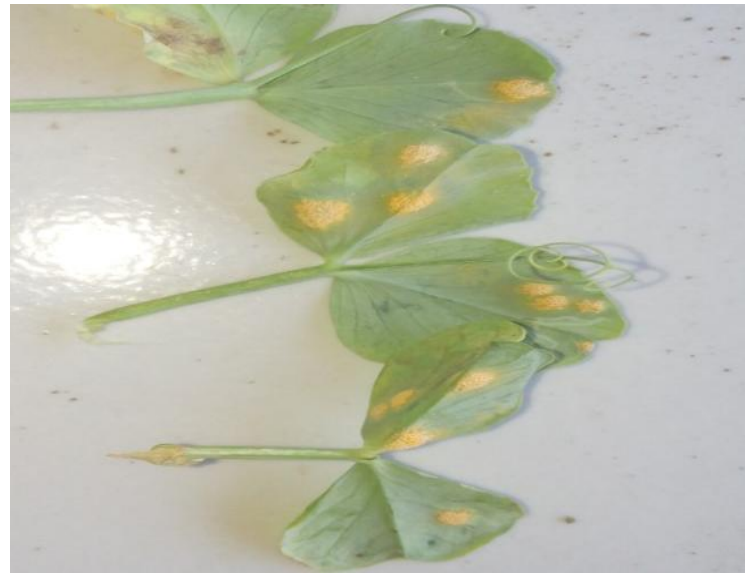

Fig.3 Powdery mildew of pea

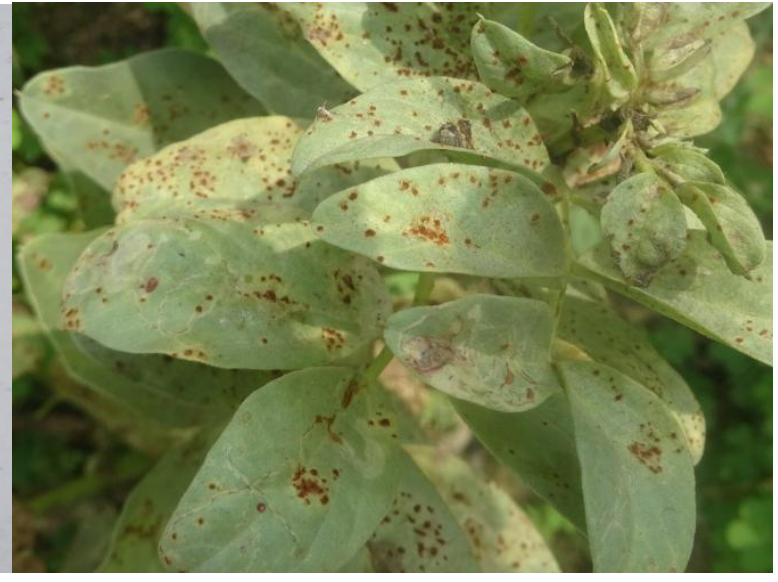

Fig.4 Wilted pea plant

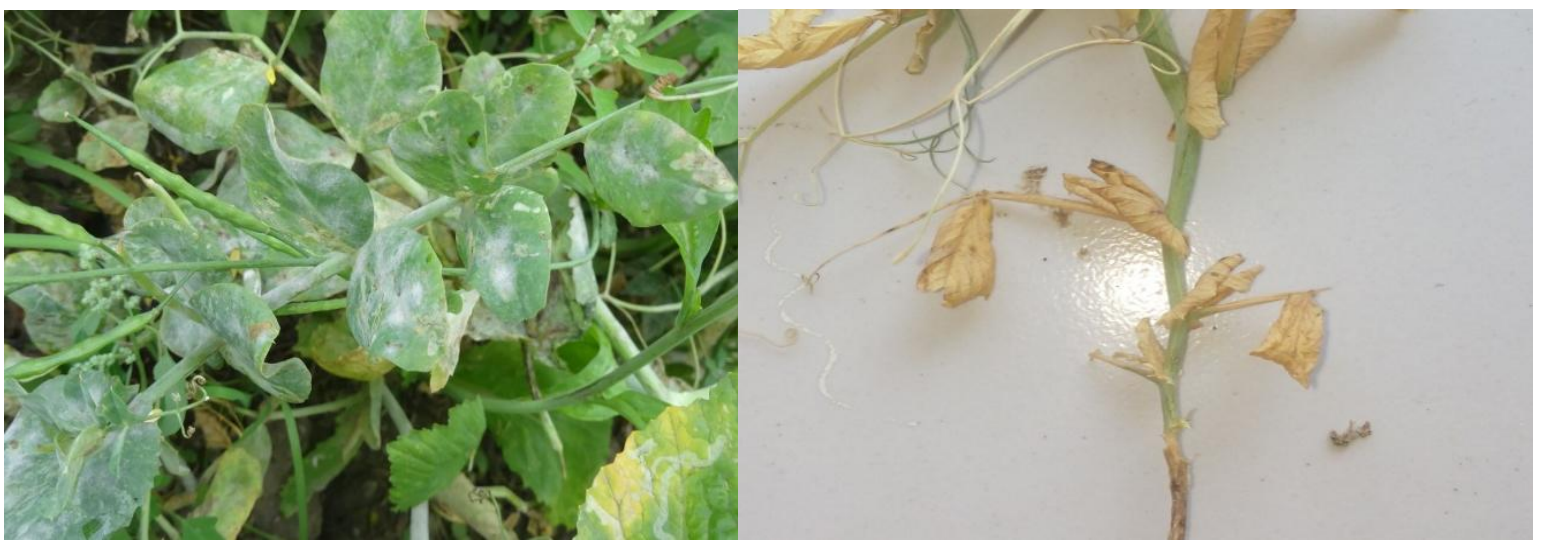


Table.1 Disease severity scale for rust in pea (Mayee and Datar, 1986)

\begin{tabular}{|c|l|}
\hline Scale Used & \multicolumn{1}{c|}{ Remarks } \\
\hline 0 & leaf and fruit free from infection \\
\hline 1 & $1-5$ leaves are infected \\
\hline 2 & $6-20 \%$ leaves are infected \\
\hline 3 & $21-40 \%$ leaves and fruits are infected \\
\hline 4 & $41-70 \%$ leaves and fruits are infected \\
\hline 5 & above 70\% leaves and fruits are infected \\
\hline
\end{tabular}

Table.2 Disease severity scale for powdery mildew infection (Saari and Prescott, 1975)

\begin{tabular}{|l|l|}
\hline Scale Used/leaf area affected & \multicolumn{1}{c|}{ Remarks } \\
\hline $0=0 \%$ & Absolutely free from any pustules of powdery mildew. \\
\hline $1=0.1-5 \%$ & One or 2 pustules on few leaves \\
\hline $2=5.1-10 \%$ & Few pustules on some leaves \\
\hline $3=10.1-17 \%$ & Few isolated pustules on most of the leaves \\
\hline $4=17.1-25 \%$ & Many pustules on most of the leaves \\
\hline $5=25.1-50 \%$ & Many pustules coalescing to each other \\
\hline $6=50.1-75 \%$ & Coalescing pustules on almost whole plant \\
\hline $7=75.1-90 \%$ & Almost uniform powdery growth covering leaves and pods \\
\hline $8=90.1-95 \%$ & $\begin{array}{l}\text { Uniform powdery growth without any conspicuous pustules } \\
\text { on the leaves, pods and stem }\end{array}$ \\
\hline $9=95.1-100 \%$ & $\begin{array}{l}\text { Whole plant covered with powdery mass giving light greyish } \\
\text { white appearance leading to premature drying of plants }\end{array}$ \\
\hline
\end{tabular}

Table.3 Percent occurrence of rust, powdery mildew and wilted pea and broad bean plants

\begin{tabular}{|l|l|l|l|l|}
\hline \multirow{2}{*}{$\begin{array}{l}\text { Name of the } \\
\text { disease }\end{array}$} & \multicolumn{2}{|c|}{ \% incidence } \\
\cline { 2 - 5 } & \multicolumn{2}{|c|}{ Imphal } & \multicolumn{2}{c|}{ Chandel } \\
\cline { 2 - 5 } & Pea & Broad bean & Pea & Broad bean \\
\hline Rust & 35 & 50 & 40 & 55 \\
\hline Powdery mildew & 40 & 15 & 45 & 15 \\
\hline Wilt & 10 & 5 & 15 & 10 \\
\hline
\end{tabular}

Among the fungal diseases associated powdery mildew of pea recorded 45 percent while 15 percent disease incidence was recorded on broad bean plantin chandel district. About 40 percent of pea and 15 percent disease incidence of pea and broad bean plant was recorded respectively from Imphal district. The powdery mildew infected pea plant is shown in figure 3. Meena et al., (2011), also reported that Powdery mildew 28.4 percent were recorded in Indian mustard (Table 3). The differences in the severity of powdery mildew may be due to many factors such as the farming systems, agroclimatic conditions of the places, nutrient status, cropping systems, and disease resistance of the varieties used. The crop suffer heavy losses every year due to wilt disease, Fusarium wilt of pea is known since 1928 when Linford (1929) found it to be wide spread in the U.S.A. In India Fusarium wilt in pea was reported for the first 
time by Sukapure et al., (1957). Maheshwari et al., (1983) surveyed pea growing area in Northern India assessment of losses was found to be $13.9-95 \%$ due to wilt complex (caused by Fusarium solani $f$. sp. pisi and $F$. oxyporum $f$. sp. pisi) in Hoshiarpur district of Punjab. During 1981-83 Sharma et al., (1989) surveyed 50 villages of 6 districts in Madhya Pradesh for Fusarium wilt and wilt incidence was recorded upto 37.39 per cent. Survey of wilt incidence of pea in Eastern Uttar Pradesh ranged between 3.6 to 14.42 percent from Village to Village (198 spots) of eight districts (Jeetendra Kumar Rao, 2014). In presence investigation the wilt incidence at Imphal and Chandel district of Manipur ranged between 5-10 percent. The wilted pea plant is shown on fig 4 . The variation in occurrence of percentage of wilting in different states may be due to climatic condition, variety of seeds sowing and soil constitutions.

\section{References}

Ali M. Joshi PK. Pandey S. Asokan M. Virmani SM. Kumar R, Kandpal B.K. 2000. Legumes in the Indo-Gangetic Plain of India. (Johansen, C., et. al. Eds.). ICRISAT, Patancheru-502 324, A. P. India and Ithaca, New York, USA: Cornell University. pp. 35-70.

Anonymous. 2015. Annual Report (2014-15) on Promotion of Pulses in NEH region. ICAR-Indian Institute of Pulses Research, Kanpur, Uttar Pradesh 208024 (India).39 pp.

Chand, R.; Srivastava, C.P.; Singh, R.M. and Singh R.B. 1997. Pea specific strains in Uromyces fabae. Indian J. Pul. Res., 10:127-128.

Chauhan, R.S.; Sugha, S.K. and Singh, B.M. 1991. A note on the prevalence and distribution of pea rust in Himachal Pradesh. Him. J. Agric. Res., 17: 105107.

Dixon, G. R., 1987. Powdery mildew of vegetables and allied crops. In: D. M. Speaure. (eds), Powdery Mildew. London, UK: Academic Press. 565
Gupta, R.P. 1990. Evaluation of pea germplasm for their reaction to powdery mildew and rust. Indian J. Pul. Res., 3:186-188.

Falloon RE, Viljanen-Rollinson S.L.H. 2001. Powdery mildew. In: Kraft JM, Plfleger FL (Eds) Compendium of pea diseases and pests American phytopathological society, St. Paul, Minnesota, pp 28-29

Jeetendra Kumar Rao. 2014. Studies on survey of Fusarium wilt of pea in Eastern Uttar Pradesh. Int. J. of Life Sciences, 2(4): 359-362.

Kraft J.M. 1994. Fusarium wilts of peas (a review). Agronomic, 14(9): 561-567.

Kumar, T.B.A.; Rangaswmy, K.T. and Ravi, K. 1994. Assessment of tall field pea genotypes for slow rusting resistance. Legume Res., 17:79-82.

Linford M.B.1929. Pea disease in the U.S.A. in 1928. Pl. Dis. Rept. Supple, 67:14.

Maheshwari SK, Jhooty JS and Gupta JS. 1983. Survey of wilt and root rot of complex of pea in Northern India and the assessment of losses. Agricultural Science Digest, India 3 (3/4): 139-141

Mayee, C.D. and Datar, V.V. 1986. Phytopathometry. Technical Bulletin-1 (Special Bulletin 3), Marathwada Agric. Univ. Parbhani. p 218.

Meena, P.D, Awasthi, R.P., Godika, Sh., Gupta, J.C., Kumar, A., Sandhu, P.S., Sharma, P., Rai, P. K., Singh, Y. P., Rathi, A.S., Prasad, R., Rai, D., \& Kolte, S.J. 2011. Eco - friendly approaches managing major diseases of Indian mustard. World Applied Science Journal, 12, 1192 1195.

Prasada, R. and Verma, U.N. 1948. Studies on lentil rust, Uromyces fabae. Indian Phytopathol, 1: 142-146.

Roy, T. C. 1949. Fungi of Bengal: Directorate of Agriculture. Govt. of West Bengal.

Saari E.E, Prescott J.M. 1975. A scale for appraising foliar intensity of wheat diseases. Plant Diseases Reporter 59: 377380.

Sharma, A.K. 1998. Epidemiology and management of rust disease of French bean. Veg. Sci., 25:85-88. 
Sharma BL, Parasar RD and Sudh Bohre, 1989. Studies on survey of wilt of in Nothern region of Madhya Pradesh. Legume Research, 12(3): 151-152.

Smith PH, Foster EM, Boyd LA, Brown J.K.M. 1996. The early development of Erysiphe pisi on Pisum sativum L. Plant Pathol 45:302-309

Sukapure RS, Bhide VP and Patel M.K. 1957. Fusarium wilt of garden pea (Pisum sativum L.) in Bomby State. Indian Phytopath., 10:11-17.

Maheshwari SK and Gandhi S.K. 1998. Fusarium wilt and root rot of pea: a review. Agriculture Reviews (Karnal), 19(4): 239-249.

Munjal RL, Chenulu VV, Hora T.S. 1963. Assessment of losses due to powdery mildew (Erysiphe polygoni) on pea. Indian Phytopathol 19:260-267

Narsinghani, V.G.; Singh, S.P. and Pal B.S. 1980. Note on rust resistance pea varieties. Indian J. Agric. Sci., 50:453

Sokhi, H.S.; Sokhi, S.S. and Rawal, R.D. 1974. Vertical reaction of pea to powdery mildew (Erysiphe polygoni) and rust (Uromyces vicia fabae). Mysore J. Agril. Sci., 8:529-532.

Warkentin TD, Rashid KY, Xue A.G. 1996. Fungicidal control of powdery mildew in field pea. Can J Plant Sci 76:933-935

Gritton ET, Ebert R.D. 1975. Interaction of planting date and powdery mildew on pea plant performance. Am Soc Horti Sci 100:137-142?

Falloon RE, Viljanen-Rollinson SLH 2001. Powdery mildew. In: Kraft JM, Plfleger FL (eds) Compendium of pea diseases and pests American phytopathological society, St. Paul, Minnesota, pp 28-29
Lin YS (1991) the occurrence of pea wilt and its control in Taiwan. Plant Protection Bulletin (Taipei) 33(1):36-44

Linford MB (1929) Pea disease in the U.S.A. in 1928. Pl. Dis. Rept. Supple, 67:14.

Maheshwari SK, Jhooty JS and Gupta JS (1983) Survey of wilt and root rot of complex of pea in Northern India and the assessment of losses. Agricultural Science Digest, India 3 (3/4): 139-141.

Munjal, R. L., V. V. Chenulu and T. S. Hora. Assessment of losses due to powdery mildew (Erysiphe polygoni) on pea, Indian Phytopathology. 19: 260-267, 1963.

Phal R and Choudhury B (1983) Fusarium wilt of garden pea: race situation. Indian Journal of Agricultural Science, 53(9): 863-865.

Sharma BL, Parasar RD and Sudh Bohre (1989) Studies on survey of wilt of in Northern region of Madhya Pradesh. Legume Research, 12(3): 151-152.

Singh AK, Kumar Prevesh (2009). Nutrient management in rainfed dryland agro eosystem in the impending climate change scenario. Agric. Situation in India LXVI (5):265-270.

Singh AK, Bhat BP, Sundaram PK, Chndra N, Bharati RC, Patel SK (2012a). Faba bean (Vicia faba L.) phenology and performance in response to its seed size class and planting depth. Int. J. Agric. Stat. Sci. 8(1):97-109

Sukapure RS, Bhide VP and Patel MK (1957) Fusarium wilts of garden pea (Pisum sativum L.) in Bomby State. Indian Phytopath., 10:11-17.

\section{How to cite this article:}

Nabakishor Nongmaithem, Ch. Basudha and Susheel Kumar Sharma. 2017. Incidence of Rust, Powdery Mildew and Wilt in Pea and Broad bean Plant of Manipur, India. Int.J.Curr.Microbiol.App.Sci. 6(8): 2611-2616. doi: https://doi.org/10.20546/ijcmas.2017.608.310 